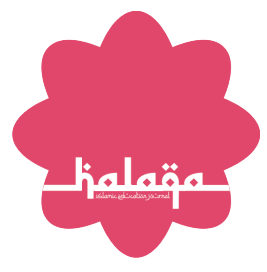

OPEN ACCESS ISSN 2503-5045 (online) ISSN 1412-9302 (print)

*Correspondence: Khizanatul Hikmah khizanah.hikmah@gmail.com

Received: 25 November 2019 Accepted: 10 Desember 2019 Published: 21 Februari 2020

Citation:

Hikmah K, Farikha A and Amrullah M (2020) Kitabah Error Analysis Based on Theory of Rusydi Ahmad Thuaimah.

. 4:1.

doi: 10.21070/halaqa.v4i1.174

\section{Kitabah Error Analysis Based on Theory of Rusydi Ahmad Thuaimah Analisa Kesalahan Kitabah Berbasis Teori Rusydi Ahmad Thuaimah}

\author{
Khizanatul Hikmah*, Anis Farikha, Muhlasin Amrullah \\ Fakultas Agama Islam, Universitas Muhammadiyah Sidoarjo, Indonesia
}

This research is about writing error analysis based on Rusydi Ahmad Thuaimah's theory which aims to analyze writing errors in students of Islamic Education in $3^{\text {rd }}$ semester 2018-2019 UMSIDA. Respondents in this study were students of PAI 3rd semester 20182019. Data collection in this study uses documentation methods, questionnaires, and literature studies. The results of this study are factors in writing (Imlak) of $3^{\text {rd }}$ semester students of islamic studies in 2018-2019 UMSIDA, Factor internal language: Not yet know the writing of harakat hijaiyah properly and correctly, difficulty in distinguishing hijaiyah letters with almost the same pronunciation, difficulty in distinguishing letters that are spoken with written ones. The solution to the obstacles faced by students of islamic studies in $3^{\text {rd }}$ semester 2018-2019 UMSIDA in Maharah Kitabah (Imlak) is by building a mindset and easy motivation and being able to write Arabic words or sentences in accordance with the correct rules, making students familiar with imlak by maximizing the lecture time, given concepts related to the absolute rules correctly.

Keywords: Writing Error, Rusydi Ahmad Thuaimah's theory

Penelitian ini mengenai analisa kesalahan kitabah berbasis teori Rusydi Ahmad Thuaimah yang bertujuan untuk untuk melakukan analisa kesalahan kitabah pada mahasiswa Pendidikan Agama Islam Semester III 2018-2019 UMSIDA. Responden dalam penelitian ini adalah mahaiswa PAl semester 3 2018-2019. Pengumpulan data dalam penelitian ini menggunakan metode dokumentasi, kuesioner, dan studi pustaka. Hasil penelitian ini adalah Factor intern bahasa : Belum mengetahui penulisan harakat hijaiyah secara baik dan benar, kesulitan dalam membedakan huruf hijaiyah yang pengucapannya hampir sama, kesulitan dalam membedakan huruf yang diucapkan dengan yang ditulis. Solusi dari kendala yang dihadapi Mahasiswa Prodi PAI Semester 3 2018-2019 UMSIDA dalam Maharah Kitabah (Imlak) yaitu dengan membangun mindset dan motivasi mudah dan bisa dalam menulis kata atau kalimat bahasa arab sesuai dengan kaidah yang benar.

Keywords: Kesalahan Kitabah, Teori Rusydi Ahmad Thuaimah 


\section{PENDAHULUAN}

Setiap bahasa adalah komunikatif bagi para penuturnya, artinya bahasa memiliki kesamaan dengan bahasa lainnya dalam statusnya, yaitu sebagai media komunikasi. Disamping kesamaan sebagai alat komunikasi, tentunya setiap bahasa memiliki keunikan dan ciri khas yang berbeda antara bahasa satu dengan yang lainnya. Diantaranya bahasa arab, bahasa yang kaya sekali akan kosakata, memiliki ciri khas dalam struktur bahasanya, lahjah, mempunyai kepustakaan besar disemua bidang ilmu pengetahuan, dan lain-lain.

Mempelajari bahasa asing, termasuk bahasa arab tentunya akan berbeda dengan belajar bahasa ibu atau pertama, oleh karenanya dasar pengajarannya berbeda, baik metode, materi hingga proses pelaksanaan pembelajaran. Adapun keterampilan (Maharah) pada pembelajaran bahasa arab meliputi keterampilan menyimak (istima'), keterampilan berbicara (Kalam), keterampilan membaca (Qiroah), dan keterampilan menulis (Kitabah). Dari keempat keterampilan tersebut proses awal dimana pembelajaran bahasa terjadi, dan tidak dapat dipisahkan karena saling berkaitan antara satu dengan yang lainnya.

Maharah Kitabah merupakan salah satu dari empat keterampilan dalam bahasa arab dengan mengerahkan perasaan dan pemikirannya sehingga menghasilkan sebuah tulisan. Dapat dikatakan pula bahwa menulis merupakan salah satu keteranpilan berbahasa yang digunakan dalam komunikasi secara tidak langsung, tidak didapatkan secara alamiah namun melalui proses belajar dan berlatih sehingga perlu adanya pembinaan dalam keterampilan menulis Wagiran (2005) . Adalah keterampilan terakhir yang harus dikembangkan setelah kemahioran menyimak, kalam dan qiro'ah. Bahkan dikatakan sebagai keterampilan tertinggi dari keempat keterampilan berbahasa Kamal (2010) . Dengan demikian keterampilan menulis sebagai salah satu sarana komunikasi bahasa tulis antara seseorang dengan orang lain dengan menuangkan perasaan, ide, gagasan serta pemikirannya yangb tidak terbatas oleh waktu dan tempat.

Menulis dalam bahasa arab (Maharah al-Kitabah) terdapat dua aspek kemampuan yang harus dikembangkan, yaitu kemampuan teknis dan kemapuan ibddi (produksi). Yang dimaksud dengan kemampuan teknis adalah kemampuan menulis bahasa arab dengan benar, meliputi kebenaran imlak (tulisan), qawaid (susunan) dan penggunaan alamaat al-tarqim (tanda baca) Hamid (2010) .

Adapun salah satu ruang lingkup dari keterampilan menulis (maharahkitabah) yaitu imla'. Imla' merupakan dikte atau bagian atau jenis dari keterampilan menulis (Kitabah) yang memperhatikan aspek kemampuan menulis secara tepat dan benar melalui penguacapan kata dengan meletakkan tanda baca secara tepat Mảrifatul (2009). Dengan kata lain, suatu kemampuan teknis atau tata cara dalam menulis bahasa arab secara baik dan benar dengan memperhatikan kaedah penulisan melalui keaktifan indra pendengaran, pengucap dan peraba (tangan).
Namun pada realitanya, banyak terdapat problematika didalam pembelajaran bahasa arab terutama dalam pembelajaran imla. Menurut madzkur bahwa diantara penyebab kesalahan tulisan siswa atau mahasiswa adalah sebagian huruf ada yang diucapkan namun tidak ditulis, dan sebagian ada yang tidak diucapkan dan juga tidak ditulis pula Alim (1975) . Disisi lain pembelajaran bahasa arab di Indonesia meliputi dua aspek yaitu aspek kebahasaan dan non kebahsaan. Fokus pada aspek kebahasaan meliputi tataran bunyi, kata, struktur, makna dan tulisan. Sehingga pada aspek kebahasaan inilah yang menjadi hal utama dalam kajian pembelajaran imla'.

Prodi Pendidikan Agama Islam merupakan salah satu prodi dalam Fakultas Agama Islam Universitas Muhammadiyah Sidoarjo yang bertujuan membentuk sarjana muslim yang memiliki keahlian dibidang agama Islam dengan harapan lulusan Prodi PAI dapat menjadi tenaga pendidik Agama islam pada sekolah dasar dan menengah, pengawas PAI, peneliti, maupun pengelola lembaga pendidikan. Guna mencapai tujuan dan harapan dari lulusan prodi PAI, salah satu mata kuliah yang wajib ditempuh oleh mahasiswa PAI semester tiga yaitu Maharah Kitabah. Diantara tujuan pembelajaran Maharah Kitabah ini agar siswa mampu menulis bahasa arab sebagai bahasa agama islam yang sesuai dengan kaidahkaidah penulisan arab yang baku, mentransfer bunyi huruf, menuangkan kata atau ide ke dalam sebuah tulisan bahasa arab secara benar. Realita yang terjadi berdasarkan pengamatan peneliti, sebagian mahasiswa belum mampu menulis bahasa arab sesuai dengan kaidah yang benar. Ketika terjadi kesalahan dalam penulisan maka akan berakibat perubahan makna yang tidak sesuai dengan makna yang akan disampaikan. Masih terdapat pula kesalahan-kesalahan yang muncul dalam tulisan mahasiswa Pendidikan Agama Islam Semester III 2018-2019 UMSIDA diantaranya penulisan kaidah tanda baca, hamzah dll. Oleh karena itu, Dalam studi kasus ini, peneliti berusaha mengkaji secara mendalam dan detail dengan menganalisa kesalahan-kesalahan penulisan kitabah (Imla') berbasis konsep Rusydi Ahmad Thuaimah. Yang kemudian mahasiswa akan diberikan treatment berupa kaedah penulisan imla' atau memberikan pemahaman dalam mendalami imlak yang harus dipelajari dan dikuasai sebagai seorang mahasiswa perguruan tinggi Pendidikan Agama Islam agar sesuai dan tecapai dari visi dan misi prodi PAI.

\section{METODE PENELITIAN}

Penelitian ini menggunakan pendekatan metode kualitatif Error Analysis Sugiyono (2007), analisis kesalahan ini dimaksudkan untuk menganalisa kesalahan-kesalahan penulisan kitabah (Imla') mahasiswa PAI Semester tiga 2018-2019 berbasis konsep Rusydi Ahmad Thuaimah yang meliputi tiga langkah yaitu identifikasi kesalahn (Ta’rif al-akhtho'), deskripsi dan klasifikasi kesalahan (Tausif al-khata'), serta penafsiran dan penjelasan kesalahn (tafsir al-akhtha'). Penelitian ini dilakukan selama enam bulan dari bulan November 2018 sam- 
pai April 2019 dengan objek penelitian adalah objek penelitian adalah tulisan-tulisan mahasiswa yang diambil dari hasil UTS. Responden dalam penelitian ini adalah mahaiswa PAI semester 3 2018-2019. Pengumpulan data dalam penelitian ini menggunakan metode dokumentasi, kuesioner, dan studi pustaka S. (1989). Adapun teknik analisa data yang digunakan peneliti disini adalah berdasarkan teori rusydi ahmad thuaimah kemudian peneliti melakukan teknik analisa hitung dengan rumus sebagai berikut : Mulyana (2001)

\section{$\mathrm{P}=\frac{F_{\mathrm{X}}}{N} 100 \%$}

\section{HASIL DAN PEMBAHASAN}

\section{Kesalahan Dalam Tulisan (Imlak) Mahasiswa Prodi PAI Semester 3 2018-2019 UMSIDA}

Diantara kesalahan dalam maharah kitabah (Imlak) pada mahasiswa prodi PAI semester 3 2018-2019 dapat diklasifikasikan sebagai berikut :

\section{Penulisan Harakat}

Berbicara huruf arab sama halnya dengan huruf hijaiyah, maka huruf hijaiyah tersebut tidak akan bisa dibaca kecuali diberi tanda baca (Harakat/Syakal). Adapun tanda syakal atau harakat tersebut adalah fathah, kasrah, dhommah, tanwin, sukun dan tasydid. Berdasarkan pengamatan yang dilakukan peneliti melalui hasil UTS mahasiswa prodi PAI semester 3 2018-2019, ditemukan kesalahan-kesalahan dalam penulisan harakat diantaranya :

\section{Harakat Panjang}

Dibawah ini adalah data kesalahan Imlak terkait penulisan harakat panjang :

[Table 1 about here.]

Analisis Tabel 1 : dalam penulisan harakat panjang ini ditemukan 3 mahasiswa yang menuliskan kata syadiidun tanpa menambahkan huruf ya' sukun. Bentuk penulisan harakat panjang pada kata tersebut dapat dilihat dalam kolom pembenaran.

Dari tabel Tabel 1 diatas, dapat diketahui prosentase kesalahan dalam penulisan harakat panjang yang terjadi pada mahasiswa PAI semester 3 2018-2019 sebagai berikut :

$$
3 \times 100 \%=15 \%
$$

20

Prosentae kesalahan dalam penulisan harakat panjang yang terjadi pada mahasiswa PAI semester 3 2018-2019 memiliki tingkat kesalahan sebanyak 15\%.

\section{Tanwin Fathah}

Sebagaimana dalam pembahasan sebelumnya, bahwa tanwin fathah merupakan salah satu tanda baca pada tulisan arab yang pada akhir kata tersebut diucapkan dengan bunyi nun sukun ('n') atau layaknya bertemu dengan huruf nun mati. Tabel 2 dibawah ini adalah data kesalahan Imlak terkait penulisan harakat pendek :

[Table 2 about here.]

Analisis Tabel 2 : Dalam penulisan harakat tanwin fathah ini pada kata WXXditemukan 2 mahasiswa yang menuliskan kata tersebut tanpa menambahkan huruf alif diakhir kata. Bentuk penulisan harakat tanwin fathah yang benar pada kata tersebut dapat dilihat dalam kolom pembenaran. Selain itu,

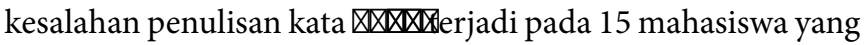
menuliskan kata tersebut sebagaimana pada kolom bentuk kesalahan diatas. Adapun pembenaran kata tersebut dapat dilihat pada kolom pembenaran dengan menggunakan huruf Kho' , tanpa alif lam ta'rif diawal dan diakhiri dengan fathatain atau tanwin fathah.

Dari Tabel 2 diatas, dapat diketahui prosentase kesalahan dalam penulisan tanwin fathah pada kata Syadiidan yang terjadi pada mahasiswa PAI semester 3 2018-2019 sebagai berikut

$$
\begin{aligned}
& 2 \times 100 \%=10 \% \\
& 20
\end{aligned}
$$

Presentasi kesalahan dalam penulisan tanwin fathah pada kata Syadiidan yang terjadi pada mahasiswa PAI semester 3 2018-2019 memiliki tingkat kesalahan sebanyak 10\%.

Adapun prosentase kesalahan dalam penulisan tanwin fathah pada kata Khubzan yang terjadi pada mahasiswa PAI semester 3 2018-2019 sebagai berikut :

\begin{tabular}{|l|}
\hline$\overline{15} \times 100 \%=75 \%$ \\
20
\end{tabular}

Presentasi kesalahan dalam penulisan tanwin fathah pada kata Khubzan yang terjadi pada mahasiswa PAI semester 3 2018-2019 memiliki tingkat kesalahan sebanyak 75\%.

\section{Asy-Syamsiyah dan Al-Qomariyah}

Selaras dengan pembahasan pada kajian teori sebelumnya, alif lam syamsiyah apabila bertemu dengan huruf hijaiyah syamsiyah yang berjumlah 14 huruf maka cara memebacanya dengan dimasukkan atau diidghomkan kepada huruf syamsiyah. Sebaliknya jika alif lam qomariyah, apabila bertemu salah satu huruf qomariyah yang berjumlah 14 huruf maka cara membacanya harus dengan diidzharkan atau jelas dan terang. Dibawah ini adalah data kesalahan Imlak terkait penulisan alSyamsiyah dan al-Qomariyah sebagai berikut : 
[Figure 1 about here.]

Analisis : Berdasarkan paparan data Gambar 1 kesalahan diatas diketahui bahwa kesalahan imlak yang terjadi pada mahasiswa PAI semester 3 2018-2019 yaitu terkait alif lam al-qomariyah. Adalah pertama pada kata dimana, ditemukan 18 mahasiswa yang menuliskan kata tersebut tidak sesuai dengan kaidah penulisan imlak yang baik dan benar sebagaimana terlihat pada kolom bentuk kesalahan diatas, diantaranya menyambungkan huruf ba' dengan lam, menyambungkan huruf ba' dengan ya' sukun, memanjangkan mim, memisahkan huruf ba' dengan al-basmalah, dan menggunakan alif lam ta'rif pada kata al-basmalah. Adapun Bentuk penulisan alif lam al-qomariyahpada kata bi al-basmalah yang benar dapat dilihat dalam kolom pembenaran. Kedua, kesalahan penulisan kata terjadi pada 5 mahasiswa yang menuliskan kata tersebut sebagaimana pada kolom bentuk kesalahan diatas, diantaranya fa' yang disambungkan dengan huruf lam, huruf fa' yang disambungkan dengan huruf lam dan 'ain pada kata fi al-'asl, menggunakan huruf hamzah yang seharusnya huruf 'ain pada kata 'asal. Adapun pembenaran kata dilihat pada kolom pembenaran dengan menggunakan huruf fa yang disambungkan dengan huruf ya' sukun, menggunakan alif lam tảrif dan diikuti selanjutnya dengan huruf 'ain.

Dari Gambar 1 diatas, dapat diketahui prosentase kesalahan dalam penulisan alif lam qomariyah pada kata bi albasmalah yang terjadi pada mahasiswa PAI semester 3 20182019 sebagai berikut :

$$
\frac{18 \times}{20} 100 \%=90 \%
$$

Artinya, Presentasi kesalahan dalam penulisan alif lam qomariyah pada kata bi al-basmalah yang terjadi pada mahasiswa PAI semester 3 2018-2019 memiliki tingkat kesalahan sebanyak $90 \%$.

Adapun prosentase kesalahan dalam penulisan tanwin fathah pada kata fi al-'Asali yang terjadi pada mahasiswa PAI semester 3 2018-2019 sebagai berikut:

$$
5 \times 100 \%=25 \%
$$$$
20
$$

Dengan kata lain, Presentasi kesalahan dalam penulisan alif lam qomariyah pada kata fi al-Asali yang terjadi pada mahasiswa PAI semester 3 2018-2019 memiliki tingkat kesalahan sebanyak $25 \%$.

Dengan demikian dapat disimpulkan bahwa kesalahan penulisan alif lam qomariyah pada kata bi al-basmalah mencapai $90 \%$ dan pada kata fi al-'asal sebanyak $25 \%$.

a. Hamzah
Telah dijelaskan pada pembahasan sebelumya bahwa antarahamzahdan alif adalah dua huruf yang berbeda. Jika hamzah dapatmenerima harakat, maka alif tidak dapat menerima harakat, sebagaimana pada kata " $\| \mathbb{}$ " Kata tersebut adalah sebuah kata yang diawalioleh huruf alif dan ia bukanlah huruf hamzah, oleh karenanya pada huruf awalnya dibaca "aliflâm -mîm" bukan "hamzah-lâm -mîm" atau "â - lâm -mîm". Dibawah ini adalah data kesalahan Imlak terkait penulisan hamzah sebagai berikut :

\section{[Figure 2 about here.]}

Analisis :

1) Hamzah yang terletak diawal kata

Berdasarkan uraian data kesalahan diatas diketahui bahwa kesalahan imlak yang terjadi pada mahasiswa PAI semester 3 2018-2019 yaitu terkait hamzah yang terletak diawal katapada hamzah qothi' adalah pada kata sep hamzah yang terletak diawal kata pada hamzah qoth', apabila posisi hamzah diatas alif atau dibawahnya diawali dengan huruf jar, athaf, al-mảrifah dan yang lainnyamaka ia tidak akan pernah berubah pada posisinya. Pertama ditemukan 9 mahasiswa yang menuliskan kata sesuai dengan kaidah penulisan imlak yang baik dan benar sebagaimana terlihat pada kolom bentuk kesalahan diatas, diantaranya menggunakan mim ya' nun diakhir kata bukan fathatain, menggunakan huruf 'ain pada kata aaalamin, memanjangkan huruf 'ain. Adapun Bentuk penulisan kata bi aalamin yang benar dapat dilihat dalam kolom pembenaran no.1. Kedua, kesalahan penulisan hamzah yang terletak diawal kata pada hamzah washal kata tersebut sebagaimana pada kolom bentuk kesalahan diatas, diantaranya huruf nun sukun dan nunyang seharusnya dimasukkan menjadi satu sehingga menjadi tasydid dan dipanjangkan satu alif, menyambungkan huruf lamdengan ya' yang seharusnya tanpa pemberian ya' layyinah, dan yang lainnya sebagaimana tertera pada kolom bentuk kesalahan no 6 . Adapun pembenaran kata pembenaran (No. 6) yaitu dengan membuang alif lam ta'rif diawal kata An-Nas dikarenakan terdapat lam jar sebelum kata An-Nas.

\section{KESIMPULAN}

Bentuk kesalahan dalam Imlak Mahasiswa Prodi PAI Semester 3 2018-2019 UMSIDA adalah kesalahan penulisan harakat panjang pada kata

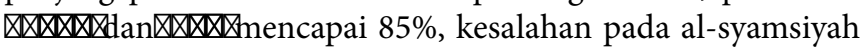
dan al-qamariyah pada kata kata mencapai 25\%, kesalahan dalam penulisan hamzah diawal kata pada hamzah qoth'i dalam kata $45 \%$ dan hamzah washal pada kata hamzah yang terletak ditengah kata pada kata pai $40 \%$, kata penulisan hamzah diakhir kata di atas huruf alif $(\mathbb{\Xi})$ pada 
kata memiliki tingkat kesalahan sebanyak $45 \%$, kesalahan penulisan huruf hijaiyah pada kata kata2010 kesalahan penulisan alif layyinah ditengah kata dan ditulis alif mamdudah pada kata

Faktor kesalahan dalam tulisan (Imlak) Mahasiswa Prodi PAI Semester 3 2018-2019 UMSIDA, diantaranya Factor intern mahasiswa yaitu belum menguasai teknik menulis arab sesuai kaidah yang benar, kesulitan dalam menulis hamzah, belum mengetahui penulisan huruf hijaiyah yang disambung dan tidak disambung, belum terbiasa mendengar kosakata bahasa arab, kurangnya konsentrasi dalam Imlak, Factor intern bahasa : Belum mengetahui penulisan harakat hijaiyah secara baik dan benar, kesulitan dalam membedakan huruf hijaiyah yang pengucapannya hampir sama, kesulitan dalam membedakan huruf yang diucapkan dengan yang ditulis.

Solusi dari kendala yang dihadapi Mahasiswa Prodi PAI Semester 3 2018-2019 UMSIDA dalam Maharah Kitabah (Imlak) yaitu dengan membangun mindset dan motivasi mudah dan bisa dalam menulis kata atau kalimat bahasa arab sesuai dengan kaidah yang benar, membuat mahasiswa terbiasa dengan imlak dengan memaksimalkan waktu perkuliahan, diberikan konsep terkait kaidah imlak dengan benar, mengenalkan dan memberikan kosakata bahasa arab yang lebih banyak, membiasakan untuk konsentrasi dalam imlak, mengoptimalkan club bahasa arab dilingkungan fakultas tarbiyah dan muamalah.

Dari tabel diatas, dapat diketahui prosentase kesalahan dalam penulisan hamzahdiawal kata pada kata terjadi pada mahasiswa PAI semester 3 2018-2019 adalah :

$$
\frac{9 \times}{20} 100 \%=45 \%
$$

Sedangkan prosentase kesalahan dalam penulisan hamzahdiawal kata pada kata PAI semester 3 2018-2019 sebagai berikut :

\section{$\frac{11 \times x}{100 \%}=59 \%$}

Disimpulkan bahwa kesalahan penulisan hamzah diawal kata pada hamzah qoth'I dalam kata hamzah washal pada kata

1) Hamzah yang terletak ditengah kata

Selaras dengan kaidah imlak, bahwa penulisan hamzah ditengah kata terdapat 3 bentuk yaitu dengan, $\mathbb{\nabla}$, . $\mathbb{\nabla}$ Penulisan hamzah ditengah kata dengan huruf $\mathbb{\otimes}$ apabilahamzah berharakat fathah dan huruf sebelumnya berharakat fathah seperti dalam kata pengamatan peneliti terdapat 8 mahasiswa yang mengalami kesalahan penulisan hamzah ditengah kata dengan menggunakan huruf . $\nabla$ Diantara kesalahan tersebut yaitu beberapa mahasiswa menuliskan kata 'ain yag seharusnya ditulis hamzah, menggunakan huruf yang $\rrbracket$ seharusnya $\rrbracket$, dan tidak memberikan huruf hamzah diatas melainkan menggunakan alif. Disisi lain, Penulisan hamzah ditengah kata dengan huruf apabila $\bigotimes$ hamzah berharakat kasrah seperti

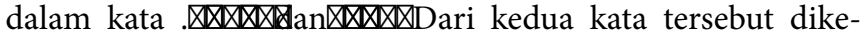
tahui hamzah berharokat kasrahmeskipun keduanya memiliki kedudukan yang berbeda, sebagai ran dhomatain dan sebagai fathatain. Hasil pengamatan peneliti bahwa dari kata terdapat 9 mahasiswa yang mengalami kesalahan penulisan hamzah ditengah kata dengan menggunakan huruf antara $\rrbracket$ lain menuliskan hamzah ditengah kata namun tidak meng-

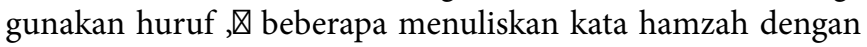
huruf 'ain. Memendekkan huruf sin diawal kata, meuiskan huruf ya' namun tidak diberi huruf hamzah diatas ya'. Selain itu dalam kata terdapat $\triangle \times \square \times \square$ mahasiswa yang mengalami kesalahan penulisan hamzah ditengah kata dengan menggunakan huruf antara $\mathbb{X}$ lain menuliskan hururf hamzah dengan ,$\bigotimes$ menuliskan hamzah dengan huruf 'ain, dan lain-lain seperti pada kolom bentuk salah diatas.

Sehingga dari tabel diatas, dapat diketahui prosentase kesalahan dalam penulisan hamzahditengah kata pada kata WDAang terjadi pada mahasiswa PAI semester 3 2018-2019 adalah :

$$
\frac{3 x}{20} 100 \%=40 \%
$$

Sedangkan prosentase kesalahan dalam penulisan hamzahditengah kata pada kata PAI semester 3 2018-2019 adalah :

$\frac{9 \times 100 \%=45 \%}{20}$

Dan kesalahan penulisan pada kata

$\frac{5 x}{20} 100 \%=25 \%$

1) Hamzah yang terletak diakhir kata

Dalam rumus kaidah imlak, posisi hamzah ditulis di atas huruf alif( $(\mathbb{X})$ diakhir kata apabila didahului oleh huruf berharakat fathah. Misal pada kata , bungkan dengan dhomir (kata ganti orang) tetap ia dituliskan dengan huruf $(\mathbb{\nabla})$ diakhir kata sebab ia didahului oleh huruf berharakat fathah. Realita bahwa terjadi kesalahan penulisan hamzah diakhir kata dengan huruf alif( $(\mathbb{\Xi})$ terjadi pada mahasiswa PAI semester 3 2018-2019 sebanyak 9 orang. Diantara kesalahan tersebut berupa huruf hamzah yag seharusnya ditulis dengan $(\bigotimes)$ namun ditulis dengan huruf 'ain, hamzah dengan bentuk penulisan diatas ya', hamzah yang berdiri sendiri , (『) penulisan hamzah dengan hururf kaf, penulisan huruf ta' dengan ta' marbuthoh.

Disimpulkan bahwa penulisan hamzah dengan di atas huruf alif(囚) diakhir kata pada kata sebanyak $45 \%$ dari

$$
\frac{9 x}{20} 100 \%=45 \%
$$




\section{a. Huruf Hijaiyah}

Unsur huruf bahasa arab dalam disebut juga sebagai huruf hijaiyah. Diketahui bahwa huruf hijaiyah berjumlah 28 buah, dan diantara huruf tersebut terdapat huruf yang dapat disambung dan tidak dapat disambung. Data kesalahan dalam penulisan huruf hijaiyah pada mahasiswa PAI semester 3 kami paparkan dalam bentuk tabel berikut:

[Figure 3 about here.]

Analisis :

Berdasarkan pengamatan peneliti bahwa terdapat kesalahan penulisan huruf hijaiyah pada mahasiswa PAI semester 3 2018-2019, beberapa kesalahan penulisan tersebut yaitu pada kata yang seharusnya tertulis menggunakan hururf syinnamun ditulis dengan huruf sin, harusnya menggunakan hururf hamzah diawal kata namun menggunakan huruf ain, menuliskan huruf hamzah ditengah kata dengan ( $\nabla)$ sebagaimana tertera pada kolom bentuk kesalahan pada no. 1. Apabila diprosentasekan, maka kesalahan tersebut sebanyak $25 \%$ (5 dari 20 mahasiswa) diketahui dari :

$$
\frac{5 \times 100 \%}{20}=25 \%
$$

Kesalahan penulisan huruf hijaiyah kedua pada kata sebanyak 4 mahasiswa. Kesalahan penulisan tersebut adalah 2 mahasiswa menggunakan huruf sin diawal, dan 2 mahasiwa lainya menggunakan huruf sha diawal sebagaimana pada tabel diatas. Jumlah prosentase dari kesalahan tersebut adalah $20 \%$ yang diketahui dari :

$\frac{4 x}{20} 100 \%=20 \%$

a. Alif Layyinah ditengah Kata

Aliflayyinah ditengah kata ditemukan baik di isim, fi'il maupun harfdan ditulis mamdudahatau thawilah adalah alif yang berdiri tegak seperti galah. Ditemukan data kesalahan penulisan alif layyinah ditengah kata yang ditulis dalam alif mamdudah atau thawilah terjadi pada mahasiswa PAI semester 3 2018-2019 sebanyak 4 orang pada kata Diantara. han tersebut adalah tanpa menggunakan alif mamdudah ditengah kata dan diakhir kata tidak menggunakan hamzah melainkan huruf 'ain, serta memanjangkan harakat pada huruf fa'. Secara rinci kami paparkan dalam bentuk tabel berikut :

[Figure 4 about here.]

Dengan demikian, diketahui prosentase kesalahan dalam penulisan alif layyinahditengah kata pada kata jadi pada mahasiswa PAI semester 3 2018-2019 adalah : $20 \%$ dari hasil
1. Faktor kesalahan dalam tulisan (Imlak) Mahasiswa Prodi PAI Semester 3 2018-2019 UMSIDA

Berdasarkan pengamatan dari kesalahan Imlak diatas sekaligus data kuesioer yang telah didapatkan peneliti dari responden (mahasiswa), maka factor kesalahan atau kesulitan yang terjadi dalamImlakmahasiswa prodi PAI semester 32018 2019 diantaranya :

a. Factor intern mahasiswa : belum mengetahui teknik menulis arab atau ayat sesuai dengan kaidah yang bai dan benar, kesulitan dalam menulis alif yang terletak ditengah maupun diakhir kata, belum mengetahui secara benar tentang penulisan arab atau huruf hijaiyah yang disambung dan tidak disambung, belum terbiasa mendengar kosakata bahasa arab sehingga kesulitan dalam menyambungkan huruf menjadi sebuah kata, pendengaran yang kurang tajam dan kurangnya konsentrasi dalam Imlak. Terjadinya kesalahan atau kesulitan dalam imlak ini disebabkan karena kurangnya latihan dalam imlak, beberapa dari mahasiswa mengungkapkan mata kuliah maharah kitabah (Imlak) merupakan mata kuliah yang baru dikenal dan dipelajaridiperguruan tinggi, kurangnya pemahaman dalam menuliskan huruf hijaiyah yang disambung dan tidak disambung, tidak terbiasa dalam menulis arab atau huruf hijaiyah, kurangnya penguasaan terkait kaidah imlak, latar belakang sebagian mahasiswa bukan berasal dari madrasah atau pesantren,

b. Factor intern bahasa : Belum mengetahui penulisan harakat panjang, pendek atau tanwin secara baik dan benar, Kesulitan dalam membedakan huruf hijaiyah yang pengucapannya hampir sama atau mirip misalnya $\bigotimes$ dengan , $\bigotimes$ kesulitan dalam membedakan huruf yang diucapkan dengan yang ditulis.

2. Solusi dari kendala yang dihadapi Mahasiswa Prodi PAI Semester 3 2018-2019 UMSIDA dalam Maharah Kitabah (Imlak)

Untuk meminimalisir kesalahan yang terjadi dalam imlak dari mahasiswa PAI semester 3 2018-2019 adalah :

a. Membangun mindset dan motivasi bahwa seorang muslim khususnya mahasiswa UMSIDA PAI dapat menulis kata atau kalimat bahasa arab sesuai dengan kaidah yang benar serta mudah dalam menuliskannya.

b. Membuat mahasiswa agar terbiasa dengan imlak yakni memaksimalkan waktudalam mata kuliah maharah kitabah, hal ini dapat dilakukan dengan drill.

c. Mahasiswa diberikan konsep terkait kaidah menulis arab atau imlak dengan benar

d. Mengenalkan dan memberikan kosakata bahasa arab yang lebih banyak, yang familiar digunakan dilingkungan sekolah.

e. Membiasakan mahasiswa untuk konsentrasi dan memperhatikan setiap huruf yang dibacakan, makhroj serta panjang pendek dari kata yang dibacakan dengan ejaan yang tidak terlalu cepat.

f. Mengoptimalkan club bahasa arab dilingkungan fakultas tarbiyah dan muamalah sebagai jembatan dan memfasilitasi mahasiswa yang kurang optimal dalam bahasa arab khususnya 
maharah kitabah (Imlak).

\section{KESIMPULAN}

1. Bentuk kesalahan dalam Imlak Mahasiswa Prodi PAI Semester 3 2018-2019 UMSIDA adalah kesalahan penulisan harakat panjang pada kata pada kata mencapainan an alsyamsiyah dan al-qamariyah pada kata mencapain $90 \%$ dan kata mencapai $25 \%$, kesalahan dalam penulisan hamzah diawal kata pada hamzah qoth'i dalam kata mencapai mencapai 55\%, hamzah yang terletak ditengah kata pada kata mencapai kata ,\%25 alif(囚) pada kata memiliki $\%$, kesalahan penulisan huruf hijaiyah pada kataWDencapai $25 \%$ dan kata20 kesalahan penulisan alif layyinah ditengah kata dan ditulis alif mamdudah pada kata capai $20 \%$.

2. Faktor kesalahan dalam tulisan (Imlak) Mahasiswa Prodi PAI Semester 3 2018-2019 UMSIDA, diantaranya Factor intern mahasiswa yaitu belum menguasai teknik menulis arab sesuai kaidah yang benar, kesulitan dalam menulis hamzah, belum

\section{REFERENCES}

Alim, A. (1975). Al-Imlak wa at-Tarqim fi al-Kitabah (Kairo: Maktabah Ghoribah). Hamid, A. (2010). Mengukur Kemampuan Bahasa Arab Untuk Studi Islam (Malang: UIN MALIKI Press).

Kamal, H. (2010). Maharah Kitabah Wa Thariqoh Ta'Limiha. Jurnal Ulul Albab 12. Ma'rifatul (2009). Imlak Teori dan Terapan Ilmiah (Malang: UIN MALIKI Press). Mulyana, D. (2001). Metodologi Penenlitian Kualitatif (Bandung : Rosda Karya). S., N. (1989). Metode penelitin Naturalistik Kualitatif (Bandung: Tarsito). Sugiyono (2007). Memahami Penelitian Kualitatif (Bandung: Alfabeta).

Wagiran (2005). Pemerolehan Bahasa dan Pengaruhnya Terhadap Pengajaran Bahasa (Semarang: UNNES Press). mengetahui penulisan huruf hijaiyah yang disambung dan tidak disambung, belum terbiasa mendengar kosakata bahasa arab, kurangnya konsentrasi dalam Imlak, Factor intern bahasa : Belum mengetahui penulisan harakat hijaiyah secara baik dan benar, kesulitan dalam membedakan huruf hijaiyah yang pengucapannya hampir sama, kesulitan dalam membedakan huruf yang diucapkan dengan yang ditulis.

3. Solusi dari kendala yang dihadapi Mahasiswa Prodi PAI Semester 3 2018-2019 UMSIDA dalam Maharah Kitabah (Imlak) yaitu dengan membangun mindset dan motivasi mudah dan bisa dalam menulis kata atau kalimat bahasa arab sesuai dengan kaidah yang benar, membuat mahasiswa terbiasa dengan imlak dengan memaksimalkan waktu perkuliahan, diberikan konsep terkait kaidah imlak dengan benar, mengenalkan dan memberikan kosakata bahasa arab yang lebih banyak, membiasakan untuk konsentrasi dalam imlak, mengoptimalkan club bahasa arab dilingkungan fakultas tarbiyah dan muamalah.

\section{UCAPAN TERIMA KASIH}

Tak lupa kami ucapkan terimakasih kepada rekan-rekan di Universitas Muhammadiyah Sidoarjo yang selalu memberikan dukungan sehingga kami dapat menyelesaikan artikel ini.

Conflict of Interest Statement: The authors declare that the research was conducted in the absence of any commercial or financial relationships that could be construed as a potential conflict of interest.

Copyright (C) 2020 Hikmah, Farikha and Amrullah. This is an open-access article distributed under the terms of the Creative Commons Attribution License (CC BY). The use, distribution or reproduction in other forums is permitted, provided the original author(s) and the copyright owner(s) are credited and that the original publication in this journal is cited, in accordance with accepted academic practice. No use, distribution or reproduction is permitted which does not comply with these terms. 


\section{LIST OF FIGURES}

Kesalahan Al-Syamsiyah dan Al-Qomariyah . . . . . . . . . . . . . . . . . . . . 53

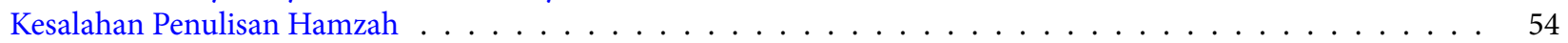

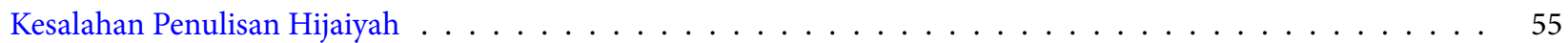

Kesalahan Penulisan Alif Layyinah . . . . . . . . . . . . . . . . . . . . . . . . . . . . . 56 


\begin{tabular}{|c|c|c|c|}
\hline No. & Bentuk Salah & Bentuk Benar & Jumlah Kesalahan \\
\hline \multirow{4}{*}{1} & بِلٌْ بَسْمَلَة & \multirow{4}{*}{ بِالْبَسْمَلَةِ } & 8 \\
\hline & هِيْْ بَسْمَلَكِة & & 2 \\
\hline & بِلِنْ بِسمَالَة & & 2 \\
\hline & 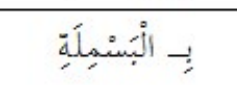 & & 2 \\
\hline & 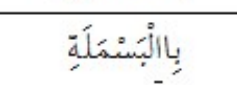 & & 4 \\
\hline \multirow[t]{4}{*}{2} & فِلْ أُسَلِ & \multirow{4}{*}{ مِِِّ الْعَسَلِ } & 1 \\
\hline & فِلْعَسَلِ & & 1 \\
\hline & 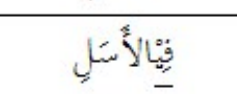 & & 2 \\
\hline & فِلْ عَسَلِ & & 1 \\
\hline
\end{tabular}

FIGURE 1 | Kesalahan Al-Syamsiyah dan Al-Qomariyah 


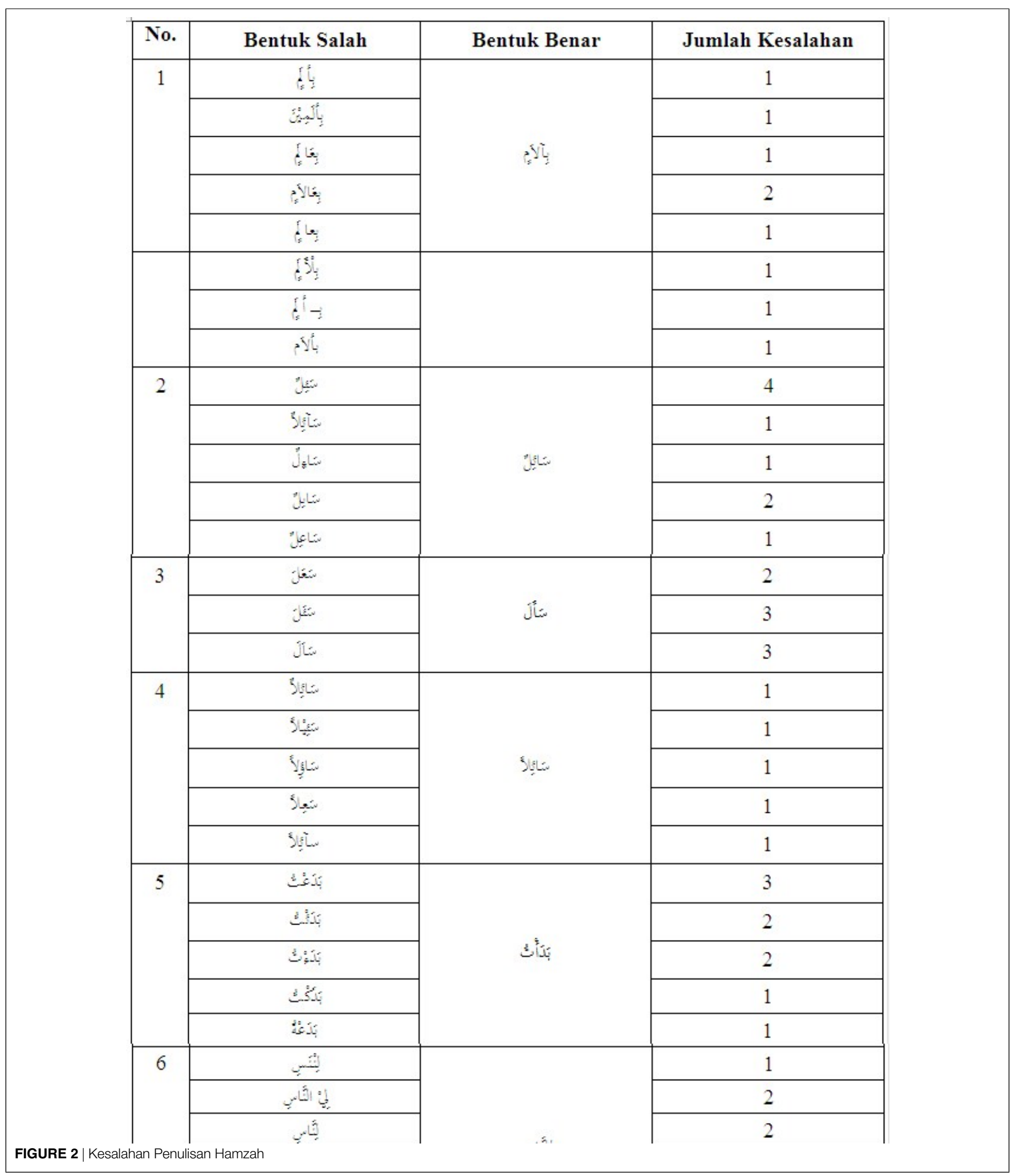




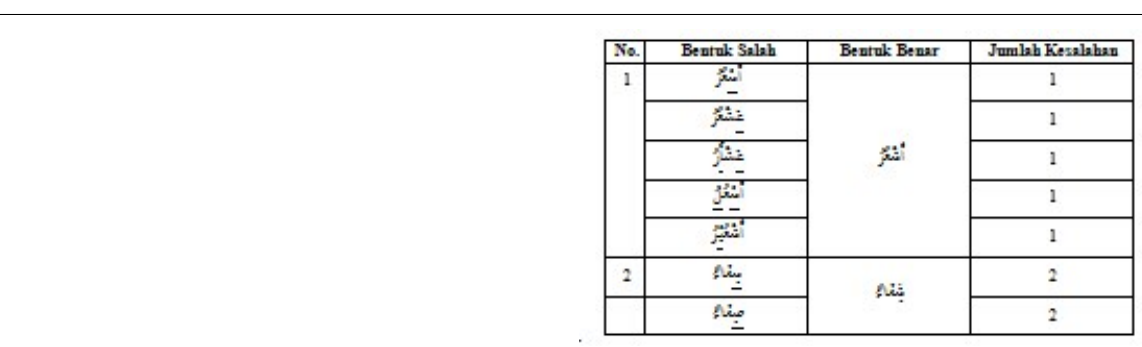

FIGURE 3 | Kesalahan Penulisan Hijaiyah 


\begin{tabular}{|c|c|c|c|}
\hline No. & Bentul Salah & Bentuk Benar & Jumlahkesalabar \\
\hline \multirow[t]{2}{*}{1} & بش & \multirow{2}{*}{ ئش } & 1 \\
\hline & 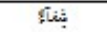 & & 3 \\
\hline
\end{tabular}

FIGURE 4 | Kesalahan Penulisan Alif Layyinah 


\section{LIST OF TABLES}

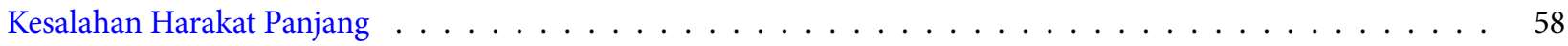

59 
TABLE 1 | Kesalahan Harakat Panjang

Jumlah Kesalahan

1

3 
TABLE 2 | Kesalahan Tanwin Fathah

No Bentuk Salah

Jumlah Kesalahan

1

rer

2

2

2

2

2

9 